\title{
Young adults' self-sufficiency in daily life: the relationship with contextual factors and health indicators
}

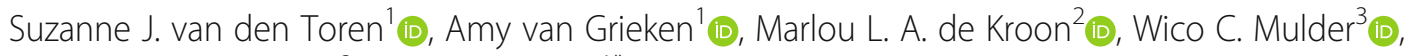
Yvonne T. M. Vanneste ${ }^{3}$ (D) and Hein Raat ${ }^{1 *}$ (D)

\begin{abstract}
Background: Certain factors, such as depressive symptoms and binge drinking, may be linked to young adults' ability to attain an acceptable level of functioning on specific life-domains (i.e. self-sufficiency). We studied the association of contextual factors and health indicators with self-sufficiency in young adults.
\end{abstract}

Methods: We used both baseline $(n=755)$ and 6-months follow-up $(n=200)$ self-reported questionnaire data of intermediate vocational education students (16-26 years). The questionnaire included the adapted Dutch selfsufficiency matrix (SSM-D), which addresses self-sufficiency regarding 11 life-domains (e.g. finances and housing). The questionnaire also included potentially associated contextual factors (e.g. socio-demographic characteristics) and health indicators (e.g. sickness absence from school). Ordinal (overall self-sufficiency: self-sufficient on 11, 10, 9 or $\leq 8$ life-domains), and logistic (self-sufficiency per life-domain: self-sufficient yes/no) regression models were applied.

Results: The studied population was 18.6 years on average (SD 2.04), and 73.6\% were female. Cannabis use was associated with a lower overall self-sufficiency category at baseline ( $\mathrm{OR}=0.57,95 \% \mathrm{Cl}=0.33-0.99)$, as were an increase in sick days $(\mathrm{OR}=0.94,95 \% \mathrm{Cl}=0.91-0.98)$ and an increase on the scale of depressive symptoms ( $\mathrm{OR}=$ $0.87,95 \% \mathrm{Cl}=0.85-0.89)$. An increase in sick days and an increase on the scale of depressive symptoms were associated with lower odds of being self-sufficient on three and ten life-domains, respectively $(p<0.05)$. An increase on the scale of depressive symptoms was associated with a lower overall self-sufficiency category 6-months postbaseline $(\mathrm{OR}=0.90,95 \% \mathrm{Cl}=0.86-0.93)$.

Conclusions: Our findings underline the importance of addressing self-sufficiency, sickness absence, and depressive symptoms, preferably before the transition from adolescence to young adulthood has begun.

Keywords: Self-sufficiency, Young adults' functioning in daily life, Mental health, Physical health, Finances, Health risk behaviors

\footnotetext{
*Correspondence: h.raat@erasmusmc.nl

${ }^{1}$ Department of Public Health, Erasmus University Medical Center, P.O. Box 2040, 3000, CA, Rotterdam, the Netherlands

Full list of author information is available at the end of the article
}

(C) The Author(s). 2020 Open Access This article is licensed under a Creative Commons Attribution 4.0 International License, which permits use, sharing, adaptation, distribution and reproduction in any medium or format, as long as you give appropriate credit to the original author(s) and the source, provide a link to the Creative Commons licence, and indicate if changes were made. The images or other third party material in this article are included in the article's Creative Commons licence, unless indicated otherwise in a credit line to the material. If material is not included in the article's Creative Commons licence and your intended use is not permitted by statutory regulation or exceeds the permitted use, you will need to obtain permission directly from the copyright holder. To view a copy of this licence, visit http://creativecommons.org/licenses/by/4.0/. The Creative Commons Public Domain Dedication waiver (http://creativecommons.org/publicdomain/zero/1.0/) applies to the data made available in this article, unless otherwise stated in a credit line to the data. 


\section{Background}

Self-sufficiency is defined as the ability of individuals to attain an acceptable level of functioning regarding specific life-domains, such as daytime activities and social support. This ability could either be achieved by the person him/herself or by adequately organizing help from formal or informal care providers [1]. Enhancing selfsufficiency in emerging adults may contribute to a more successful transition from adolescence to adulthood [1, 2]. This transitional period is typically defined as a separate phase of emerging adulthood, a stage between adolescence and adulthood, which primarily exists in Western countries [3-5]. In this phase, adolescents transition from lower secondary school to further education or the labor market. Moreover, a transition occurs from dependence on parents to more autonomy and financial independence and from youth health care to adult health care. These transitions induce challenges for emerging adults in different life areas, e.g. finances, education and employment, leisure time activities, and physical and mental health behaviors [6-10]. These challenges might account for a decline in health status along with an increase in mental health problems and behaviors risky to health, such as binge drinking, smoking, and being physically inactive [7, 10-12]. Furthermore, the aforementioned transitions may result in a gap between the (health care) needs of emerging adults and the provision of care $[10,13,14]$. Therefore, studying self-sufficiency and potentially associated (risk) factors could inform the development of programs that aim to empower young adults' functioning in daily life. Previous research illustrated that, for instance, financial self-sufficiency can be improved by financial education to students [15], and effective mental health services in the school context can help with a successful transition to adulthood [16].

Emerging adults attending intermediate vocational education (upper secondary education with specialized job-oriented programs, ISCED 3 [17]) are expected to struggle more with becoming self-sufficient than their peers from other school levels. These emerging adults display the highest percentage of leaving school without a diploma and report relatively high levels of risk behaviors, such as more than $50 \%$ of monthly binge drinking and $45 \%$ of daily smoking $[18,19]$.

This study examined the association of contextual factors (e.g. socio-demographics and context, and risk behaviors) and indicators of health status (e.g. sickness absence and depressive symptoms) with self-sufficiency in intermediate vocational education students aged 1626 years, both cross-sectional and longitudinal. We hypothesized that less favorable contextual factors and less favorable indicators of health status will be associated with a lower likelihood of being self-sufficient.

\section{Methods}

\section{Study design}

For this study, baseline and follow-up data from the Medical Advice for Sick-reported Students (MASS) intervention evaluation study were used, which is described in more detail elsewhere [20].

The Medical Ethics Committee of the Erasmus University Medical Center Rotterdam reviewed the research proposal and declared that the Dutch Medical Research Involving Human Subjects Act (Dutch abbreviation: WMO) did not apply. They issued a declaration of no objection to conducting this study and permitted to submit the results for publication in a scientific journal in the future (proposal number MEC-2015-614). All participants provided written informed consent.

\section{Setting and study population}

A total of 22 intermediate vocational education school locations were invited to participate in the study (Fig. 1). Twelve locations could not participate, mainly because of the anticipated time investment. Finally, ten schools participated in the study in the Dutch regions of Utrecht, West-Brabant, Amsterdam, and Rotterdam. The baseline data was collected between December 2015 and October 2016. The follow-up data were collected between July 2016 and April 2017.

Participants were students aged 16-26 years attending intermediate vocational education level 1-4 (i.e. level 1 is considered assistant training and level 4 is considered middle management training). They attended the following vocational programs: media manager/developer, assistant care, trade, interior design, nursing, and technician studies. To adhere to the preferences of the schools, two different procedures were followed to select participants. (1) At eight schools, a school employee selected and invited students for participation if they had reported an extensive amount of sick days from school (i.e. reporting sick at least four times, or, more than six consecutive school days in twelve school weeks). (2).

At the two remaining schools, all students in randomly selected classes were invited to participate. The involved researcher selected students who met the criteria for extensive sickness absence afterward. All students from the first procedure and students from the second procedure who met the criteria for extensive sickness absence were placed in the 'selected sickness absence' sample. The remaining participants from the second procedure were placed in the 'general school population' sample (see Fig. 1).

All students and parents of students between 16 and 18 years of age were informed about the study through an information letter and a leaflet. These documents explained the aim of the study and included contact information of 
the researchers. An appointed coordinator from the participating schools sent the documents to the students and parents. Parents could object to having their child participate in the study by notifying their objection towards school or the researchers. The students were asked to provide written informed consent before filling out the questionnaire. The appointed coordinator collected all completed questionnaires and sent them to the researchers. Approximately 6 months later, the participants in the selected sickness absence sample (i.e. where the selection was based on the amount of sickness absence) received the follow-up questionnaire at home with a return envelope or through a link in their e-mail. The broader school sample was not invited to fill out the follow-up questionnaire. In total, 758 students provided written informed consent at baseline. Before analyses, we excluded students who were older than 26 years $(n=3)$.

\section{Measurements}

The questionnaire contained the following topics: selfsufficiency, contextual factors (i.e. socio-demographic characteristics and context, and risk behaviors), and indicators of health status (i.e. sickness absence and depressive symptoms).

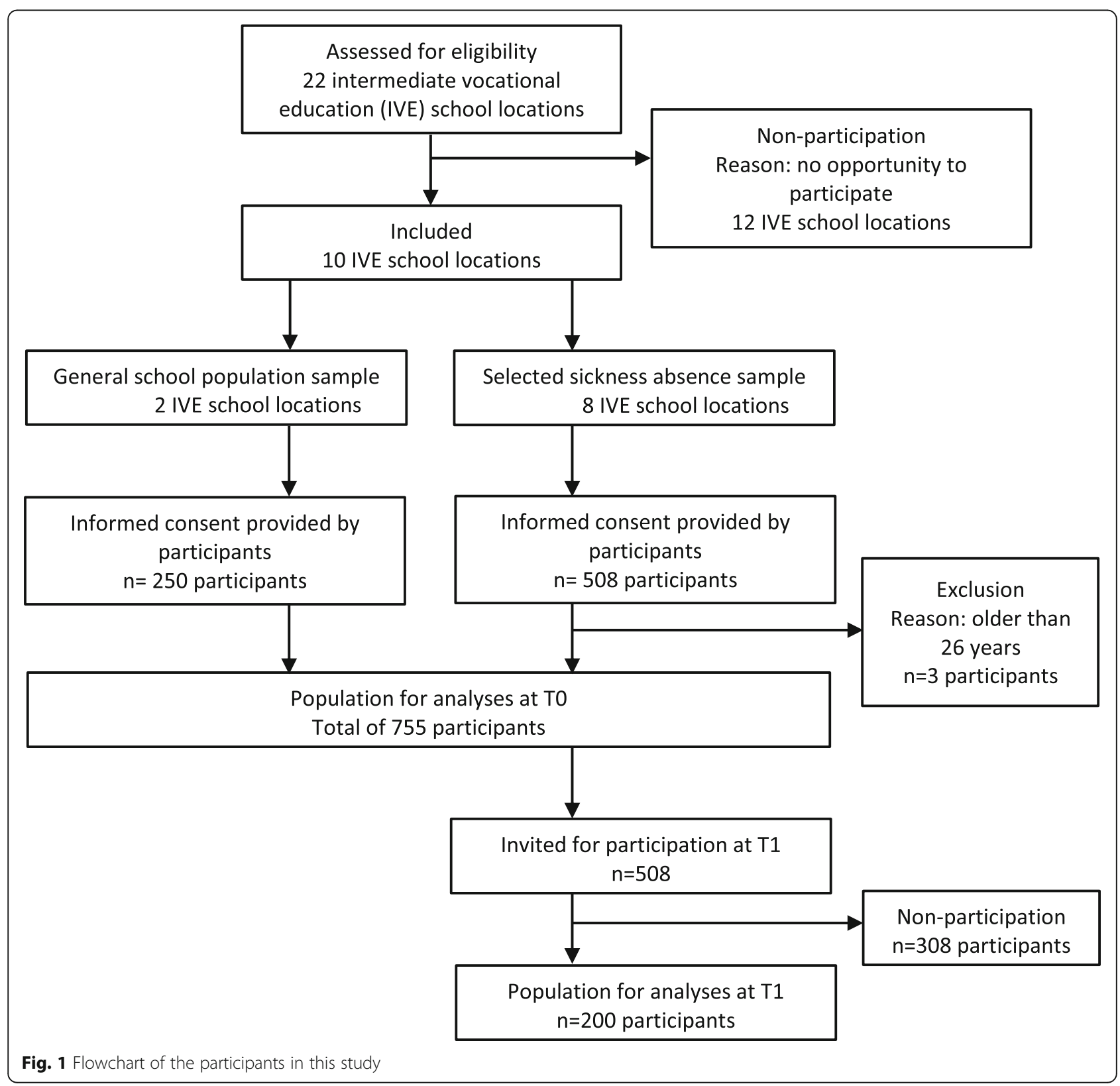




\section{Self-sufficiency}

An adapted version of the Dutch self-sufficiency matrix (SSM-D) was included in the questionnaire [1, 21]. This version was developed for and validated among students attending intermediate vocational education, corresponding to the language skills of the students, and addresses the ability of students to provide for themselves regarding 11 specific life-domains (finances, daytime activities, housing, domestic relations, mental health, physical health, addiction, activities daily life, social network, community participation, and judicial) [21]. Each life-domain was assessed by how many problems the student had in the past 6 months in a certain life-domain, e.g. 'Finances. Think of: having the money to make ends meet' (Additional file 1: Table A1). Five response categories ranged from 'no problems' to 'many problems'. Response categories were dichotomized into 'self-sufficient' (few problems and no problems) versus 'not to barely self-sufficient' (many problems to not few/not many problems) for each life-domain. For analyses purposes, one overall selfsufficiency score was calculated, ranging from selfsufficient on all life-domains, ten life-domains, nine lifedomains, and eight or fewer life-domains.

\section{Contextual factors and indicators of health status}

Elements of the International Classification of Functioning, Disability, and Health (ICF) from the World Health Organization were used to select relevant factors [22, 23]. In this framework, human functioning is considered at the level of the whole person in a social context. We applied an adapted version of this framework to our study (Additional file 2: Figure B1).

\section{Contextual factors}

Socio-demographics and context included age (years), gender (boy/girl), level of intermediate vocational education (higher level 4 vs. lower levels 1-3), ethnic background (Dutch versus non-Dutch by following the definition of Statistics Netherlands [24]), living situation, and perceived school performance. For living situation, ten different response categories were dichotomized into 'living with a caretaker' versus 'living without a caretaker'. Perceived school performance was assessed by the question: "How do you think your teacher estimates your school performance compared to your classmates?". Five response categories ranged from 'very good' to 'not good', and were dichotomized into 'good' versus 'average or less'. Previous research showed this item can distinguish students who get good grades at school from students that do not [25].

Risk behaviors included cigarette smoking, binge drinking, cannabis use, delinquency, and truancy. Cigarette smoking was assessed by the question: "How often do you currently smoke?”. Four response categories ranged from 'not' to 'yes, daily' and were dichotomized into 'current smoking' versus 'no current smoking'. Binge drinking was assessed by the question: "How many times did you consume five or more alcoholic drinks on one occasion in the past four weeks?", by following the international definition of binge drinking [26]. Seven response categories ranged from 'never' to 'nine or more times' and were dichotomized into 'not once' versus 'one or more times'. Cannabis use was assessed by the number of times the student had used cannabis over the past 4 weeks. Eight response categories ranged from 'never' to ' 20 or more times' and were dichotomized into 'not once' versus 'one or more times'. Criminal behavior was assessed by ten items covering criminal behavior in the past 6 months (e.g. bought stolen goods). Ten response categories ranged from 'never' to 'six times' or more. All ten items were merged into one dichotomous item 'no criminal behavior' versus 'at least one criminal behavior' in the past 6 months. Truancy was assessed by the question: "Have you been truanting in the past four weeks?". Six response categories ranged from 'no truancy' to 'more than 20 hours of truancy', and were categorized into 'never', ' $1-5 \mathrm{~h}$ ' and 'more than 5 hours' [27].

\section{Indicators of health status}

Sickness absence was assessed by the question: "How many days in the past eight school weeks did you stay home from school, because you were sick? (do not count holidays)" [27]. The continuous score for number of sick days was used. Depressive symptoms were assessed using the validated Center for Epidemiologic Studies Depression scale (CES-D) $[28,29]$. The CES-D is a 20-item scale used to determine the clinical relevance of depression. The items cover the main components of depressive symptoms such as depressed mood, guilt, feelings of helplessness, loss of appetite, and sleep. The frequency of experiencing these symptoms in the past week was assessed. Four response categories ranged from 'always' to 'hardly ever'. The continuous total CES-D score was used with higher scores indicating higher levels of depressive symptoms (range of 0-60).

\section{Data analyses}

Descriptive statistics were used to describe the sociodemographic characteristics of the study population (Table 1). We compared participants who completed both the baseline and follow-up questionnaire with participants lost to follow-up using chi-square tests (for categorical variables) and independent sample $t$-tests (for continuous variables) (Additional file 3: Table C1). Also, descriptive statistics were used to show the distribution of students who were self-sufficient and who were not self-sufficient in each life-domain at baseline and 6 months post-baseline (Table 2).

We examined associations of contextual factors and indicators of health status (i.e. predictor variables) with 
Table 1 Socio-demographic characteristics of the study population at baseline $(N=755)$

\begin{tabular}{ll}
\hline Socio-demographic characteristics & Total population \\
\hline Age in years, mean (SD) & \\
$\quad$ Age in years & 18.6 , range 16-26 (SD = 2.04) \\
Gender, $\mathbf{n}$ (\%) & $199(26.4)$ \\
Male & $554(73.6)$ \\
Female & $249(34.3)$ \\
Intermediate vocational education, $\mathbf{n}$ (\%) & \\
Level 1-3 & $478(65.7)$ \\
Level 4 & \\
Ethnic background, $\mathbf{n}$ (\%) & $452(60.6)$ \\
Dutch & $294(39.4)$ \\
Non-Dutch & $664(88.1)$ \\
Living situation, $\mathbf{n}$ (\%) & $90(11.9)$ \\
With parents/caretakers & \\
Not with parents/caretakers
\end{tabular}

Note: SD = Standard Deviation

${ }^{a}$ Intermediate vocational education consists of four levels: 1 = assistant training; 2 = basic vocational training; $3=$ vocational training

$4=$ middle-management training

self-sufficiency (i.e. outcome variable) using ordinal and logistic regression analyses. First, ordinal regression analyses were performed on baseline data to analyze the association between predictor variables and overall selfsufficiency at baseline as the ordinal outcome variable (ranging from self-sufficient on: all life-domains, ten life- domains, nine life-domains, and eight or fewer lifedomains) (Table 3). Second, logistic regression analyses were performed on baseline data to assess the association between predictor variables and the separate selfsufficiency life-domains as outcome variables (Tables 4). Third, ordinal regression analyses were performed to analyze the association between baseline predictor variables and overall self-sufficiency at follow-up as the ordinal outcome variable (ranging from self-sufficient on: all life-domains, ten life-domains, nine life-domains, and eight or fewer life-domains) (Table 5). We also explored interaction between gender and all other predictors in the association between baseline predictors and baseline overall self-sufficiency. No significant interaction was found.

Odds ratios (ORs) and 95\% confidence intervals (CIs) were estimated. For the ordinal regression models, we present the univariable and multivariable models. The estimated ORs represent the odds for a student to be allocated within a higher self-sufficiency category if they would have scored one point higher on a predictor variable [30].

We considered a $p$-value of 0.05 or lower to be statistically significant. All analyses were performed using SPSS version 25 (IBM Corp. Released 2017. IBM SPSS Statistics for Windows, Version 25.0. Armonk, NY: IBM Corp.).

\section{Results}

\section{Participant characteristics}

Participants were on average 18.6 years old $(\mathrm{SD}=2.04$, with a minimum age of 16 years and a maximum age of 26 years); $73.6 \%$ were female and $60.6 \%$ were classified

Table 2 Baseline and 6-months follow-up distribution of overall self-sufficiency and of the separate self-sufficiency life-domains

\begin{tabular}{|c|c|c|c|c|}
\hline \multirow[t]{2}{*}{ Time-point } & \multicolumn{4}{|l|}{ Overall self-sufficiency } \\
\hline & On 11 life-domains $\mathrm{n}$ (\%) & On 10 life-domains $\mathbf{n}(\%)$ & On 9 life-domains n (\%) & On $\leq \mathbf{8}$ life-domains $\mathrm{n}(\%)$ \\
\hline Baseline $(n=755)$ & $265(36.6)$ & $116(16.0)$ & $103(14.2)$ & $240(33.1)$ \\
\hline \multirow[t]{2}{*}{ Follow-up $(n=200)$} & $58(32.4)$ & $38(21.2)$ & $20(11.2)$ & $63(35.2)$ \\
\hline & \multicolumn{2}{|l|}{ Baseline $(n=755)$} & \multicolumn{2}{|c|}{ 6-months follow-up $(n=200)$} \\
\hline Finances & $537(73.5)$ & $194(26.5)$ & $130(72.2)$ & $50(27.8)$ \\
\hline Daytime activities & $545(75.0)$ & $182(25.0)$ & $147(81.7)$ & $33(18.3)$ \\
\hline Housing & $661(90.4)$ & $70(9.6)$ & $171(95.0)$ & $9(5.0)$ \\
\hline Domestic relations & $591(80.8)$ & $140(19.2)$ & $142(78.9)$ & $38(21.1)$ \\
\hline Mental health & $437(60.0)$ & $291(40.0)$ & $97(53.9)$ & $83(46.1)$ \\
\hline Physical health & $520(71.1)$ & $211(28.9)$ & $116(64.4)$ & $64(35.6)$ \\
\hline Addiction & $663(90.7)$ & $68(9.3)$ & $168(93.3)$ & $12(6.7)$ \\
\hline Daily life skills & $678(92.7)$ & $53(7.3)$ & $161(89.4)$ & 19 (10.6) \\
\hline Social network & $631(86.3)$ & $100(13.7)$ & $151(83.9)$ & $29(16.1)$ \\
\hline Community participation & $566(77.4)$ & $165(22.6)$ & $142(78.9)$ & $38(21.1)$ \\
\hline Judicial & 715 (97.8) & $16(2.2)$ & 178 (98.9) & $2(1.1)$ \\
\hline
\end{tabular}

a Self-sufficiency was measured on eleven life-domains. Participants indicated whether they were able to provide for themselves regarding these life-domains. Five response categories ranged from 'no problems' to 'many problems'. Response categories were dichotomized into 'self-sufficient' versus 'not to barely selfsufficient' for each life-domain 
as Dutch (Table 1). Results of the lost to follow-up analysis showed that participants lost to follow-up were more often male $(p<0.05)$, were lower educated $(p<$ $0.001)$ and more often had a non-Dutch ethnic background $(p<0.001)$ than participants included at both time-points (see additional file 3: Table C1).

The judicial life-domain had the highest number of self-sufficient participants at baseline (97.8\%) and at follow-up (98.9). The three life-domains with the lowest number of self-sufficient participants were 'finances' (at baseline 73.5\%, at follow-up 72.2\%), 'mental health' (at baseline $60.0 \%$, at follow-up 53.9\%), and 'physical health' (at baseline $71.1 \%$, at follow-up 64.4\%) (Table 2).

\section{Results of the regression analyses}

Table 3 shows the associations of contextual factors and indicators of health status with overall self-sufficiency at baseline, as assessed with ordinal regression analyses. In de multivariable model, young adults using cannabis were at risk of having a lower overall self-sufficiency category $(\mathrm{OR}=$ $0.57,95 \% \mathrm{CI}=0.33$ to 0.99 ), as were young adults with more sick days from school $(\mathrm{OR}=0.94,95 \% \mathrm{CI}=0.91$ to 0.98 ), and young adults with a higher score on the depressive symptoms scale $(\mathrm{OR}=0.87,95 \% \mathrm{CI}=0.85$ to 0.89$)$.

Tables 4 presents the results of the associations of contextual factors and indicators of health status with the separate self-sufficiency life-domains at baseline, assessed with logistic regression analyses. An increase in sick days was associated with lower odds of being selfsufficient on three life-domains, ORs varied from 0.92 to 0.95. An increase on the scale of depressive symptoms was associated with lower odds of being self-sufficient on ten life-domains, ORs varied from 0.81 to 0.96 .

Table 5 shows the results of the associations of contextual factors and health status at baseline with overall self-sufficiency at follow-up, assessed with ordinal regression analyses. In de multivariable model, young adults with a higher score on the depressive symptoms scale were at risk of having a lower overall selfsufficiency category ( $\mathrm{OR}=0.90,95 \% \mathrm{CI}=0.86$ to 0.93$)$.

\section{Discussion}

This study investigated the association of young adults' self-sufficiency to function in daily life with contextual factors and indicators of health status. Our results suggest that the life-domains 'finances', 'mental health', and 'physical health' were most often reported as a problem area regarding self-sufficiency among young adults. Furthermore, young adults reporting more sick days from school or higher depressive symptom levels were less likely to be self-sufficient overall and on several lifedomains.

Our finding that a large percentage of young adults participating in our study seemed to face challenges in functioning in the life-domains of 'finances', 'mental health', and 'physical health' was partly in line with a previous study. Bannink et al. [21] studied the same eleven life-domains of self-sufficiency among a comparable sample of intermediate vocational education students aged 18.3 years on average. Similar to our study, they reported that the life-domains 'finances' and 'mental health' were the most challenging areas. However, the second largest problem area in their study was 'domestic relations', while in our study, this was 'physical health' (i.e. physical self-sufficiency regarding sickness and the ability to deal with the sickness). Furthermore, their study showed overall fewer problems in being self-sufficient on all life-domains. These differences could be explained by an overrepresentation of young adults who display extensive sickness absence as a result of our sample selection, in which we purposely aimed to select more students with extensive sickness absence.

Overall, especially indicators of health status (i.e. sickness absence and depressive symptoms) were related to diminished overall self-sufficiency and self-sufficiency on specific life-domains, for instance 'daytime activities' and 'social network'. These findings concur with previous research where mental disorders were found to affect daily functioning by limiting personal, social, and work life [31]. And where depressive symptom levels among adolescents were inversely related to life satisfaction, and academic and emotional self-efficacy [32, 33]. Finally, absence from school, either due to sickness or truancy, was found to be related to low levels of academic achievements and antisocial or risky behaviors, such as ineffective coping [34, 35].

Cannabis use was related to diminished overall selfsufficiency in the ordinal regression analyses, but not in the logistic regression analyses for the separate lifedomains. This difference may be due to the fact that cannabis users had the likelihood of falling especially into the group that was self-sufficient on eight or fewer life-domains on the ordinal variable (data are not shown). This suggests that cannabis users are more likely to have trouble with self-sufficiency on multiple life-domains simultaneously.

The finding that young adults who do not live with a caretaker are less self-sufficient on the life-domains 'finances' and 'housing' suggests that specific attention should be given to young adults' financial situation and future housing situation, especially for those who are on the verge of moving out of their caretakers' house. Parents, school staff and youth health care professionals should be encouraged to address this, for example in the form of parental role-modeling or parental teaching and by communication between parents and their child about work [36, 37]. 
Table 3 Results of the cross-sectional ordinal regression analyses evaluating associations of contextual factors and indicators of health status with overall self-sufficiency $(n=755)$

$\begin{array}{ll}\text { Univariable model of self-sufficiency }^{\mathrm{a}} & \text { Multivariable model of self-sufficiency }^{\mathrm{b}} \\ \text { OR }(95 \% \mathrm{Cl})^{*} & \text { OR }(95 \% \mathrm{Cl})^{*}\end{array}$

\section{Contextual factors}

Socio-demographics and context

Age (in years)

$0.85(0.80 ; 0.91)$

$0.91(0.83 ; 1.00)$

Gender

Male

Ref.

Ref.

Female

$1.01(0.75 ; 1.37)$

$1.09(0.71 ; 1.65)$

Intermediate vocational education ${ }^{c}$

Level 1-3

Ref.

Ref.

Level 4

$0.62(0.47 ; 0.83)$

$0.72(0.47 ; 1.09)$

Ethnic background

\section{Dutch}

Ref.

Ref.

Non-Dutch

$1.28(0.97 ; 1.69)$

$0.98(0.66 ; 1.45)$

Living situation

With caretaker

Ref.

Ref.

Not with caretaker

$0.31(0.20 ; 0.49)$

$0.65(0.34 ; 1.25)$

Perceived school performance

$$
\begin{aligned}
& >\text { Average } \\
& \leq \text { Average }
\end{aligned}
$$

Ref.

$0.39(0.29 ; 0.52)$

$0.79(0.54 ; 1.15)$

Risk behaviors

Current smoking

No

Ref.

Ref.

Yes

$0.60(0.44 ; 0.80)$

$0.81(0.51 ; 1.27)$

Binge drinking ${ }^{d}$

0 times/ 4 weeks

Ref.

Ref.

$\geq 1$ time/4 weeks

$0.76(0.58 ; 0.99)$

$0.76(0.51 ; 1.13)$

Cannabis use

0 times/4 weeks

Ref.

Ref.

$\geq 1$ time/4 weeks

$0.44(0.31 ; 0.64)$

$0.57(0.33 ; 0.99)$

Criminal behavior

$$
\begin{aligned}
& 0 \text { times/year } \\
& \geq 1 \text { time/year }
\end{aligned}
$$

Ref.

Ref.

Truancy

$\mathrm{oh}$

Ref.

$1.19(0.70 ; 2.02)$

$1-5 \mathrm{~h}$

$0.84(0.62 ; 1.14)$

Ref.

$\geq 6 \mathrm{~h}$

$0.37(0.23 ; 0.59)$

$0.95(0.64 ; 1.41)$

$0.59(0.32 ; 1.11)$

\section{Indicators of health status}

Sickness absence (days/8 weeks)

$0.89(0.86 ; 0.91)$

$0.94(0.91 ; 0.98)$

Depressive symptoms (CES-D scale)

$0.87(0.85 ; 0.89)$

Note: Self-sufficiency was entered as an ordinal variable ranging from self-sufficient on all life-domains, self-sufficient on ten life-domains, self-sufficient on nine life-domains and self-sufficient on eight or fewer life-domains. Odds ratios represent the odds for a participant to be allocated within a higher self-sufficiency category if they would have scored one point higher on the predictor variable. Bold numbers indicate a statistically significant $(p<0.05)$ association

*Odds ratio (OR) and $95 \%$ confidence interval $(95 \% \mathrm{Cl})$ from ordinal regression analyses

${ }^{a}$ The predictor variables were entered separately in the univariable model

${ }^{\mathrm{b}}$ The predictor variables were entered simultaneously in the multivariable model

${ }^{c}$ Intermediate vocational education consists of four levels: 1 = assistant training; 2 = basic vocational training; $3=$ vocational training;

$4=$ middle-management training

${ }^{d}$ Binge drinking was defined as consuming five or more alcoholic drinks on one occasion 
Table 4 Results of the logistic regression analyses evaluating associations of contextual factors and indicators of health status with separate self-sufficiency life-domains ( $n=755)$

\begin{tabular}{|c|c|c|c|c|c|c|}
\hline & Finances & $\begin{array}{l}\text { Daytime } \\
\text { activities }\end{array}$ & Housing & $\begin{array}{l}\text { Domestic } \\
\text { relations }\end{array}$ & $\begin{array}{l}\text { Mental } \\
\text { health }\end{array}$ & Physical health \\
\hline & $\begin{array}{l}\text { OR }(95 \% \\
\text { CI)* }\end{array}$ & OR $(95 \% \mathrm{Cl})^{*}$ & $\begin{array}{l}\text { OR }(95 \% \\
\text { CI)* }\end{array}$ & OR $(95 \% \mathrm{Cl})^{*}$ & $\begin{array}{l}\text { OR }(95 \% \\
\text { Cl)* }\end{array}$ & OR $(95 \% \mathrm{Cl})^{*}$ \\
\hline \multicolumn{7}{|l|}{ Contextual factors } \\
\hline \multicolumn{7}{|l|}{ Socio-demographics and context } \\
\hline Age (in years) & $\begin{array}{l}0.84(0.75 ; \\
0.94)\end{array}$ & $\begin{array}{l}0.96(0.85 ; \\
1.09)\end{array}$ & $\begin{array}{l}1.07(0.89 ; \\
1.28)\end{array}$ & $0.98(0.86 ; 1.12)$ & $\begin{array}{l}0.91(0.79 ; \\
1.05)\end{array}$ & $0.92(0.82 ; 1.03)$ \\
\hline Gender (female) & $\begin{array}{l}1.05(0.63 ; \\
1.74)\end{array}$ & $\begin{array}{l}1.17(0.69 ; \\
2.00)\end{array}$ & $\begin{array}{l}1.15(0.52 ; \\
2.52)\end{array}$ & $0.83(0.45 ; 1.51)$ & $\begin{array}{l}0.73(0.40 ; \\
1.34)\end{array}$ & $0.81(0.48 ; 1.34)$ \\
\hline $\begin{array}{l}\text { Intermediate vocational } \\
\text { education (level } 4)^{a}\end{array}$ & $\begin{array}{l}0.78(0.46 ; \\
1.34)\end{array}$ & $\begin{array}{l}0.84(0.49 \\
1.46)\end{array}$ & $\begin{array}{l}1.03(0.44 ; \\
2.40)\end{array}$ & $0.59(0.32 ; 1.10)$ & $\begin{array}{l}0.57(0.31 \\
1.06)\end{array}$ & $1.31(0.80 ; 2.15)$ \\
\hline $\begin{array}{l}\text { Ethnic background (non- } \\
\text { Dutch) }\end{array}$ & $\begin{array}{l}0.82(0.50 \\
1.32)\end{array}$ & $\begin{array}{l}0.83(0.50 \\
1.38)\end{array}$ & $\begin{array}{l}0.47(0.23 ; \\
0.98)\end{array}$ & $0.62(0.36 ; 1.07)$ & $\begin{array}{l}1.72(0.98 ; \\
3.01)\end{array}$ & $1.33(0.83 ; 2.13)$ \\
\hline $\begin{array}{l}\text { Living situation (not with } \\
\text { caretaker) }\end{array}$ & $\begin{array}{l}0.49(0.25 ; \\
0.96)\end{array}$ & $\begin{array}{l}0.97(0.45 \\
2.06)\end{array}$ & $\begin{array}{l}0.25(0.10 ; \\
0.65)\end{array}$ & $0.59(0.27 ; 1.27)$ & $\begin{array}{l}1.50(0.62 ; \\
3.65)\end{array}$ & $0.68(0.34 ; 1.37)$ \\
\hline $\begin{array}{l}\text { Perceived school } \\
\text { performance ( } \leq \text { average) }\end{array}$ & $\begin{array}{l}0.86(0.54 ; \\
1.39)\end{array}$ & $\begin{array}{l}0.37(0.23 ; \\
0.59)\end{array}$ & $\begin{array}{l}0.73(0.36 ; \\
1.49)\end{array}$ & $0.75(0.44 ; 1.26)$ & $\begin{array}{l}0.72(0.41 ; \\
1.25)\end{array}$ & $1.02(0.64 ; 1.63)$ \\
\hline \multicolumn{7}{|l|}{ Risk behaviors } \\
\hline Current smoking (yes) & $\begin{array}{l}0.49(0.29 ; \\
0.84)\end{array}$ & $\begin{array}{l}0.91(0.52 ; \\
1.60)\end{array}$ & $\begin{array}{l}0.59(0.25 ; \\
1.40)\end{array}$ & $0.45(0.24 ; 0.83)$ & $\begin{array}{l}1.60(0.85 ; \\
3.02)\end{array}$ & $0.81(0.47 ; 1.37)$ \\
\hline $\begin{array}{l}\text { Binge drinking }{ }^{b} \text { ( } \geq 1 \text { time/4 } \\
\text { weeks) }\end{array}$ & $\begin{array}{l}0.71(0.43 ; \\
1.17)\end{array}$ & $\begin{array}{l}0.53(0.32 \\
0.90)\end{array}$ & $\begin{array}{l}0.75(0.34 ; \\
1.65)\end{array}$ & $0.96(0.54 ; 1.69)$ & $\begin{array}{l}0.69(0.39 ; \\
1.22)\end{array}$ & $1.11(0.69 ; 1.78)$ \\
\hline $\begin{array}{l}\text { Cannabis use ( } \geq 1 \text { time } / 4 \\
\text { weeks) }\end{array}$ & $\begin{array}{l}0.58(0.33 ; \\
1.04)\end{array}$ & $\begin{array}{l}0.73(0.39 \\
1.38)\end{array}$ & $\begin{array}{l}0.69(0.28 ; \\
1.67)\end{array}$ & $0.88(0.45 ; 1.72)$ & $\begin{array}{l}0.66(0.31 ; \\
1.38)\end{array}$ & $0.71(0.38 ; 1.32)$ \\
\hline $\begin{array}{l}\text { Criminal behavior ( } \geq 1 \text { time/ } 6 \\
\text { months) }\end{array}$ & $\begin{array}{l}0.69(0.38 ; \\
1.25)\end{array}$ & $\begin{array}{l}1.76(0.88 \\
3.54)\end{array}$ & $\begin{array}{l}2.09(0.71 ; \\
6.18)\end{array}$ & $0.85(0.43 ; 1.69)$ & $\begin{array}{l}1.16(0.56 ; \\
2.42)\end{array}$ & $1.44(0.75 ; 2.75)$ \\
\hline \multicolumn{7}{|l|}{ Truancy } \\
\hline 0 hours & Ref. & Ref. & Ref. & Ref. & Ref. & Ref. \\
\hline $1-5$ hours & $\begin{array}{l}1.00(0.61 ; \\
1.64)\end{array}$ & $\begin{array}{l}0.75(0.45 \\
1.25)\end{array}$ & $\begin{array}{l}0.74(0.34 ; \\
1.62)\end{array}$ & $0.77(0.45 ; 1.33)$ & $\begin{array}{l}0.73(0.42 ; \\
1.26)\end{array}$ & $1.57(0.96 ; 2.56)$ \\
\hline$\geq 6$ hours & $\begin{array}{l}0.70(0.36 ; \\
1.36)\end{array}$ & $\begin{array}{l}0.57(0.28 \\
1.15)\end{array}$ & $\begin{array}{l}1.21(0.41 ; \\
3.63)\end{array}$ & $1.37(0.61 ; 3.08)$ & $\begin{array}{l}0.69(0.30 \\
1.59)\end{array}$ & $1.93(0.93 ; 4.02)$ \\
\hline \multicolumn{7}{|l|}{ Indicators of health status } \\
\hline Sickness absence (days/8 weeks) & $\begin{array}{l}1.02(0.98 ; \\
1.05)\end{array}$ & $\begin{array}{l}0.92(0.88 ; \\
0.95)\end{array}$ & $\begin{array}{l}0.96(0.93 ; \\
1.00)\end{array}$ & $1.00(0.97 ; 1.04)$ & $\begin{array}{l}0.96(0.91 ; \\
1.01)\end{array}$ & $0.92(0.88 ; 0.95)$ \\
\hline $\begin{array}{l}\text { Depressive symptoms (CES-D } \\
\text { scale) }\end{array}$ & $\begin{array}{l}0.96(0.94 ; \\
0.98)\end{array}$ & $\begin{array}{l}0.94(0.92 ; \\
0.96)\end{array}$ & $\begin{array}{l}0.93(0.90 ; \\
0.96)\end{array}$ & $0.91(0.89 ; 0.94)$ & $\begin{array}{l}0.81(0.78 ; \\
0.84)\end{array}$ & $0.95(0.93 ; 0.97)$ \\
\hline
\end{tabular}


Table 4 Results of the logistic regression analyses evaluating associations of contextual factors and indicators of health status with separate self-sufficiency life-domains ( $n=755)$ (Continued)

\begin{tabular}{|c|c|c|c|c|c|c|}
\hline & Addiction & $\begin{array}{l}\text { Activities } \\
\text { daily life }\end{array}$ & $\begin{array}{l}\text { Social } \\
\text { network }\end{array}$ & $\begin{array}{l}\text { Community } \\
\text { participation }\end{array}$ & Judicial & $\begin{array}{l}\text { Total number of significant } \\
\text { life-domains }\end{array}$ \\
\hline & $\begin{array}{l}\text { OR }(95 \% \\
\mathrm{Cl})^{*}\end{array}$ & OR $(95 \% \mathrm{Cl})^{*}$ & $\begin{array}{l}\text { OR }(95 \% \\
\mathrm{Cl})^{*}\end{array}$ & OR $(95 \% \mathrm{Cl})^{*}$ & $\begin{array}{l}\text { OR }(95 \% \\
\mathrm{Cl})^{*}\end{array}$ & n life-domains \\
\hline \multicolumn{7}{|l|}{ Contextual factors } \\
\hline \multicolumn{7}{|l|}{ Socio-demographics and context } \\
\hline Age (in years) & $\begin{array}{l}1.11(0.93 ; \\
1.33)\end{array}$ & $\begin{array}{l}0.87(0.72 ; \\
1.06)\end{array}$ & $\begin{array}{l}0.96(0.81 ; \\
1.13)\end{array}$ & $0.98(0.87 ; 1.11)$ & $\begin{array}{l}1.23(0.81 \\
1.86)\end{array}$ & 1 \\
\hline Gender (female) & $\begin{array}{l}2.71(1.34 ; \\
5.50)\end{array}$ & $\begin{array}{l}1.46(0.58 ; \\
3.70)\end{array}$ & $\begin{array}{l}1.40(0.67 ; \\
2.91)\end{array}$ & $0.92(0.53 ; 1.59)$ & $\begin{array}{l}7.61(1.20 ; \\
48.18)\end{array}$ & 2 \\
\hline 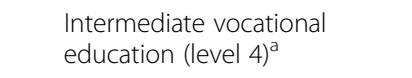 & $\begin{array}{l}0.77(0.35 \\
1.68)\end{array}$ & $\begin{array}{l}1.55(0.60 ; \\
4.03)\end{array}$ & $\begin{array}{l}1.88(0.90 ; \\
3.95)\end{array}$ & $0.45(0.25 ; 0.82)$ & $\begin{array}{l}1.14(0.21 \\
6.14)\end{array}$ & 1 \\
\hline $\begin{array}{l}\text { Ethnic background (non- } \\
\text { Dutch) }\end{array}$ & $\begin{array}{l}0.63(0.32 ; \\
1.27)\end{array}$ & $\begin{array}{l}1.12(0.47 ; \\
2.69)\end{array}$ & $\begin{array}{l}0.55(0.28 \\
1.09)\end{array}$ & $0.66(0.40 ; 1.09)$ & $\begin{array}{l}0.77(0.15 \\
4.06)\end{array}$ & 1 \\
\hline $\begin{array}{l}\text { Living situation (not with } \\
\text { caretaker) }\end{array}$ & $\begin{array}{l}0.40(0.16 ; \\
1.00)\end{array}$ & $\begin{array}{l}0.81(0.27 \\
2.46)\end{array}$ & $\begin{array}{l}0.54(0.21 ; \\
1.35)\end{array}$ & $0.71(0.34 ; 1.47)$ & $\begin{array}{l}0.34(0.03 ; \\
3.41)\end{array}$ & 2 \\
\hline $\begin{array}{l}\text { Perceived school } \\
\text { performance ( } \leq \text { average) }\end{array}$ & $\begin{array}{l}0.75(0.38 \\
1.45)\end{array}$ & $\begin{array}{l}1.25(0.54 \\
2.88)\end{array}$ & $\begin{array}{l}0.77(0.41 ; \\
1.46)\end{array}$ & $0.69(0.43 ; 1.12)$ & $\begin{array}{l}1.18(0.25 \\
5.56)\end{array}$ & 1 \\
\hline \multicolumn{7}{|l|}{ Risk behaviors } \\
\hline Current smoking (yes) & $\begin{array}{l}0.52(0.24 \\
1.14)\end{array}$ & $\begin{array}{l}1.14(0.41 \\
3.17)\end{array}$ & $\begin{array}{l}0.81(0.36 \\
1.84)\end{array}$ & $1.32(0.73 ; 2.40)$ & $\begin{array}{l}1.79(0.23 \\
13.72)\end{array}$ & 2 \\
\hline $\begin{array}{l}\text { Binge drinking }{ }^{b} \text { ( } \geq 1 \text { time/4 } \\
\text { weeks) }\end{array}$ & $\begin{array}{l}0.50(0.23 ; \\
1.08)\end{array}$ & $\begin{array}{l}0.73(0.31 ; \\
1.76)\end{array}$ & $\begin{array}{l}1.81(0.88 ; \\
3.73)\end{array}$ & $0.76(0.46 ; 1.28)$ & $\begin{array}{l}1.05(0.17 \\
6.37)\end{array}$ & 1 \\
\hline $\begin{array}{l}\text { Cannabis use ( } \geq 1 \text { time } / 4 \\
\text { weeks) }\end{array}$ & $\begin{array}{l}0.59(0.27 \\
1.28)\end{array}$ & $\begin{array}{l}0.63(0.22 ; \\
1.81)\end{array}$ & $\begin{array}{l}0.78(0.32 ; \\
1.94)\end{array}$ & $0.82(0.42 ; 1.58)$ & $\begin{array}{l}0.78(0.13 ; \\
4.68)\end{array}$ & 0 \\
\hline $\begin{array}{l}\text { Criminal behavior ( } \geq 1 \text { time/ } \\
\text { year) }\end{array}$ & $\begin{array}{l}1.03(0.45 \\
2.37)\end{array}$ & $\begin{array}{l}2.26(0.56 ; \\
9.10)\end{array}$ & $\begin{array}{l}3.92(1.22 ; \\
12.64)\end{array}$ & $0.93(0.47 ; 1.83)$ & $\begin{array}{l}0.06(0.01 ; \\
0.32)\end{array}$ & 2 \\
\hline \multicolumn{7}{|l|}{ Truancy } \\
\hline 0 hours & Ref. & Ref. & Ref. & Ref. & Ref. & \\
\hline $1-5$ hours & $\begin{array}{l}0.72(0.35 \\
1.49)\end{array}$ & $\begin{array}{l}0.66(0.27 \\
1.64)\end{array}$ & $\begin{array}{l}0.68(0.33 ; \\
1.40)\end{array}$ & $0.66(0.40 ; 1.08)$ & $\begin{array}{l}0.87(0.17 \\
4.30)\end{array}$ & 0 \\
\hline$\geq 6$ hours & $\begin{array}{l}0.93(0.36 ; \\
2.40)\end{array}$ & $\begin{array}{l}0.86(0.26 \\
2.80)\end{array}$ & $\begin{array}{l}0.47(0.18 \\
1.24)\end{array}$ & $1.25(0.58 ; 2.71)$ & $\begin{array}{l}3.69(0.22 ; \\
60.80)\end{array}$ & 0 \\
\hline \multicolumn{7}{|l|}{ Indicators of health status } \\
\hline Sickness absence (days/8 weeks) & $\begin{array}{l}0.98(0.94 ; \\
1.02)\end{array}$ & $\begin{array}{l}0.99(0.94 ; \\
1.03)\end{array}$ & $\begin{array}{l}0.95(0.92 ; \\
0.99)\end{array}$ & $1.00(0.97 ; 1.03)$ & $\begin{array}{l}1.28(0.98 ; \\
1.67)\end{array}$ & 3 \\
\hline $\begin{array}{l}\text { Depressive symptoms (CES-D } \\
\text { scale) }\end{array}$ & $\begin{array}{l}0.94(0.92 ; \\
0.97)\end{array}$ & $\begin{array}{l}0.89(0.86 \\
0.93)\end{array}$ & $\begin{array}{l}0.89(0.87 \\
0.92)\end{array}$ & $0.93(0.91 ; 0.95)$ & $\begin{array}{l}0.96(0.90 ; \\
1.03)\end{array}$ & 10 \\
\hline
\end{tabular}

*Odds ratio (OR) and 95\% confidence interval (95\% Cl) from logistic regression analyses. The full models are presented. All variables were entered simultaneously to analyze the independent association of each variable with self-sufficiency. Note: bold numbers indicate a statistically significant $(p<0.05)$ association

${ }^{a}$ Intermediate vocational education consists of four levels: $1=$ assistant training; $2=$ basic vocational training; $3=$ vocational training; $4=$ middle-management training

${ }^{b}$ Binge drinking was defined as consuming five or more alcoholic drinks on one occasion

Our findings underline the importance of early promotion of self-sufficiency, preferably before the transition from adolescence to young adulthood has begun. In this regard, it is recommended to stimulate their socialemotional competencies through social and emotional learning programs [38] and to use resilience-focused school-based interventions [39]. These resilience-focused interventions focus on resilience protective factors (e.g. personal strengths and qualities of community environments) that enable an individual to thrive and to overcome disadvantage. Also, sickness absence and depressive symptoms appear to be risk factors associated with diminished self-sufficiency and should therefore be monitored and addressed when empowering young adults in their functioning in daily life.

This study has some limitations that warrant consideration when interpreting the results. First, some factors that are possibly related to self-sufficiency were not assessed. For instance, income as a possible factor affecting (financial) self-sufficiency or dietary and sedentary 
Table 5 Results of the longitudinal ordinal regression analyses evaluating associations of contextual factors and indicators of health status with overall self-sufficiency $(n=200)$

$\begin{array}{ll}\text { Univariable model of self-sufficiency }{ }^{\mathrm{a}} & \text { Multivariable model of self-sufficiency }^{\mathrm{b}} \\ \text { OR }(95 \% \mathrm{Cl})^{*} & \text { OR }(95 \% \mathrm{Cl})^{*}\end{array}$

\section{Contextual factors}

Socio-demographics and context

Age (in years)

$0.80(0.69 ; 0.93)$

$0.96(0.78 ; 1.18)$

Gender

Male

Female

Ref.

$0.73(0.38 ; 1.38)$

Ref.

Intermediate vocational education ${ }^{c}$

Level 1-3

Ref.

Level 4

$0.78(0.39 ; 1.57)$

Ref.

$1.23(0.52 ; 2.92)$

Ethnic background

Dutch

Ref.

$0.95(0.49 ; 1.86)$

Ref.

Non-Dutch

Living situation

With caretaker

Ref.

$0.21(0.07 ; 0.61)$

Not with caretaker

Ref.

$0.59(0.32 ; 1.08)$

Ref.

$0.88(0.43 ; 1.83)$

Risk behaviors

Current smoking

No

Ref.

Ref.

Yes

$0.53(0.28 ; 1.01)$

$0.90(0.39 ; 2.07)$

Binge drinking ${ }^{d}$

0 times/4 weeks

Ref.

Ref.

$\geq 1$ time/4 weeks

$0.71(0.41 ; 1.24)$

$0.67(0.34 ; 1.35)$

Cannabis use

0 times/4 weeks

Ref.

$\geq 1$ time/4 weeks

$0.25(0.10 ; 0.60)$

Ref.

Criminal behavior

0 times/year

Ref.

$0.50(0.16 ; 1.62)$

Ref.

$\geq 1$ time/year

Truancy

$\mathrm{oh}$

Ref.

$1.10(0.60 ; 2.02)$

$0.36(0.10 ; 1.26)$

$\geq 6 \mathrm{~h}$

$0.93(0.89 ; 0.98)$

$0.98(0.93 ; 1.04)$

$0.90(0.87 ; 0.93)$
$0.90(0.86 ; 0.93)$
Depressive symptoms (CES-D scale)

Note: Self-sufficiency was entered as an ordinal variable ranging from self-sufficient on all life-domains, self-sufficient on ten life-domains, self-sufficient on nine life-domains and self-sufficient on eight or less life-domains. Odds ratios represent the odds for a participant to be allocated within a higher self-sufficiency category if they would have scored one point higher on the predictor variable. Bold numbers indicate a statistically significant $(p<0.05)$ association

*Odds ratio (OR) and $95 \%$ confidence interval $(95 \% \mathrm{Cl})$ from ordinal regression analyses

${ }^{a}$ The predictor variables were entered separately in the univariable model

${ }^{\mathrm{b}}$ The predictor variables were entered simultaneously in the multivariable model

c Intermediate vocational education consists of four levels: 1 = assistant training; 2 = basic vocational training; $3=$ vocational training;

$4=$ middle-management training

${ }^{d}$ Binge drinking was defined as consuming five or more alcoholic drinks on one occasion 
behaviors as possible factors affecting (mental) health [40-42]. Second, this study was exploratory in the sense that we used a large set of predictor variables to test for possible associations with self-sufficiency. If we would apply the Bonferroni correction for multiple testing on both the ordinal regression analyses (corrected significance level is $0.05 / 13=0.004$ ), similar results would be obtained, except for the non-significant association of cannabis use and self-sufficiency after correction. Third, the questionnaires were completed at two time points, therefore we could not infer causality. Also, a relatively large number of participants were lost to follow-up, which could have led to power problems in detecting significant associations at follow-up. A large study with multiple follow-up measures is recommended to gain insight into the direction of the associations. Lastly, our study was done in a population of students attending intermediate vocational education, which is a relatively low level of education [17]; also, there was an overrepresentation of students with extensive sickness absence from school; therefore, we recommend to repeat this study in large varied samples in other countries and settings.

\section{Conclusions}

This study assessed the association of young adults' selfsufficiency to function in daily life with contextual factors and indicators of health status. Several factors were associated with worse self-sufficiency, especially indicators of health status in the form of sick days from school and depressive symptoms. Our findings underline the importance of early promotion of self-sufficiency, preferably before the transition from adolescence to young adulthood has begun. It is recommended to stimulate adolescents' and young adults' social-emotional competencies, and to address sickness absence and depressive symptoms.

\section{Supplementary information}

Supplementary information accompanies this paper at https://doi.org/10. 1186/s40359-020-00434-0.

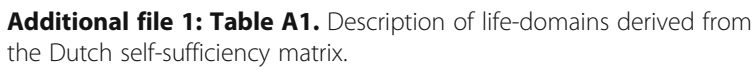

Additional file 2: Figure B1. Studied factors incorporated in the International Classification of Functioning, Disability and Health (ICF) of the $\mathrm{WHO}$.

Additional file 3: Table C1. Lost to follow-up analyses on sociodemographic characteristics $(N=755)$.

\section{Abbreviations}

ICF: International classification of functioning, disability, and health; MASS: Medical advice for sick-reported students; IVE: Intermediate vocational education; SSM-D: The Dutch version of the self-sufficiency matrix; CESD: Center for epidemiologic studies depression scale; OR: Odds ratio; $\mathrm{Cl}$ : Confidence interval; SD: Standard deviation

\section{Acknowledgements}

We are grateful for the financial support provided by ZonMw. The authors also like to express their gratitude towards the participating Youth Health Care organizations for their help with including participants and towards participating schools for their effort in participation. Finally, we would like to thank all participants for their time and energy in filling out the questionnaires.

\section{Authors' contributions}

SvdT and WM contributed to the study question. SvdT, AvG and HR contributed to the methodology and statistical approach. W and WM contributed to the data collection. MdK, HR and $\mathrm{YV}$ contributed to obtaining the grant that led to the data collection. SvdT analysed the data and drafted the manuscript. AvG and HR supervised the study. All authors contributed to the interpretation of the data, and critically revised the manuscript for important intellectual content. All authors have approved the submitted version.

\section{Funding}

This study was funded by ZonMw, the Netherlands Organization for Health Research and Development.

(project number: 531005011). The study sponsor had no role in the study design, collection, analysis and interpretation of the data, the writing and the decision to submit the manuscript for publication.

\section{Availability of data and materials}

Data are available upon reasonable request by contacting the corresponding author Hein Raat (h.raat@erasmusmc.nl).

Ethics approval and consent to participate

The Medical Ethics Committee of the Erasmus University Medical Center Rotterdam reviewed the research proposal and declared that the Dutch Medical Research Involving Human Subjects Act (Dutch abbreviation: WMO) did not apply. They issued a declaration of no objection to conducting this study and permitted to submit the results for publication in a scientific journal in the future (proposal number MEC-2015-614). All participants provided written informed consent.

\section{Consent for publication}

Not applicable.

\section{Competing interests}

No authors have conflicts of interest to report.

\section{Author details}

${ }^{1}$ Department of Public Health, Erasmus University Medical Center, P.O. Box 2040, 3000, CA, Rotterdam, the Netherlands. ²Department of Health Sciences, University Medical Center Groningen, Groningen, the Netherlands. ${ }^{3}$ Dutch Center for Youth Health (NCJ), Utrecht, the Netherlands.

Received: 10 April 2020 Accepted: 15 June 2020

Published online: 28 August 2020

\section{References}

1. Fassaert T, Lauriks S, van de Weerd S, Theunissen J, Kikkert M, Dekker J, Buster M, de Wit M. Psychometric properties of the Dutch version of the self-sufficiency matrix (SSM-D). Community Ment Health J. 2014;50(5):58390.

2. Lamborn SD, Groh K. A four-part model of autonomy during emerging adulthood: associations with adjustment. Int J Behav Dev. 2009:33(5):393401.

3. Arnett JJ. Emerging adulthood - a theory of development from the late teens through the twenties. Am Psychol. 2000;55(5):469-80.

4. Hill JM, Lalji M, van Rossum G, van der Geest VR, Blokland AAJ. Experiencing emerging adulthood in the Netherlands. J Youth Stud. 2015;18(8):1035-56.

5. Arnett JJ, Zukauskiene R, Sugimura $K$. The new life stage of emerging adulthood at ages 18-29 years: implications for mental health. Lancet Psychiatry. 2014;1(7):569-76.

6. Daw J, Margolis R, Wright L. Emerging adulthood, emergent health lifestyles: Sociodemographic determinants of trajectories of smoking, binge 
drinking, obesity, and sedentary behavior. J Health Soc Behav. 2017:58(2): 181-97.

7. Park MJ, Scott JT, Adams SH, Brindis CD, Irwin CE. Adolescent and young adult health in the United States in the past decade: little improvement and young adults remain worse off than adolescents. J Adolescent Health. 2014; 55(1):3-16.

8. Anderson EL, Steen E, Stavropoulos V. Internet use and problematic internet use: a systematic review of longitudinal research trends in adolescence and emergent adulthood. Int J Adolesc Youth. 2017;22(4):430-54.

9. Corder K, Winpenny E, Love R, Brown HE, White M, Sluijs EV. Change in physical activity from adolescence to early adulthood: a systematic review and meta-analysis of longitudinal cohort studies. Br J Sports Med. 2019; 53(8):496-503.

10. Paul M, Street C, Wheeler N, Singh SP. Transition to adult services for young people with mental health needs: a systematic review. Clin Child Psychol P. 2015;20(3):436-57.

11. Frech A. Healthy behavior trajectories between adolescence and young adulthood. Adv Life Course Res. 2012;17(2):59-68.

12. Andrews JA, Westling A. Substance use in emerging adulthood. In: Arnett JJ, editor. The Oxford handbook of emerging adulthood. New York: Oxford University Press; 2016. p. 521-42.

13. Berzin SC. Vulnerability in the transition to adulthood: Defining risk based on youth profiles. Child Youth Serv Rev. 2010;32(4):487-95.

14. Mojtabai R, Olfson M, Han B. National trends in the prevalence and treatment of depression in adolescents and young adults. Pediatrics. 2016; 138(6).

15. Fan $\mathrm{L}$, Chatterjee $\mathrm{S}$. Financial socialization, financial education, and student loan debt. J Fam Econ Iss. 2019;40(1):74-85.

16. Aviles AM, Anderson TR, Davila ER. Child and adolescent social-emotional development within the context of school. Child Adol Ment H-Uk. 2006; 11(1):32-9.

17. UNESCO. International standard classification of education - ISCED 2011. UNESCO Insitute for Statistics: Montreal, Canada; 2012.

18. DUO: Voortijdig schoolverlaten-cijferportal [Numbers on early school leaving]. Available from:https://cijfers.duo.nl/ibi_apps/bip/portal/vsv_portal. Accessed 01 February 2020 (2020).

19. Andersen $\mathrm{S}$, Rod MH, Ersboll AK, Stock C, Johansen C, Holmberg T, Zinckernagel L, Ingholt L, Sorensen BB, Tolstrup JS. Effects of a settingsbased intervention to promote student wellbeing and reduce smoking in vocational schools: a non-randomized controlled study. Soc Sci Med. 2016; 161:195-203.

20. Van der Vlis MK, Lugtenberg M, Vanneste YTM, Berends W, Mulder W, Bannink R, Van Grieken A, Raat H, de Kroon MLA. Medical advice for sick-reported students (MASS) in intermediate vocational education schools: design of a controlled before-and-after study. BMC Public Health. 2017;17(1):608.

21. Bannink R, Broeren S, Heydelberg J, van't Klooster E, Raat H. Psychometric properties of self-sufficiency assessment tools in adolescents in vocational education. BMC Psychol. 2015;3:33.

22. Momsen AH, Stapelfeldt CM, Rosbjerg R, Escorpizo R, Labriola M, Bjerrum M International classification of functioning, disability and health in vocational rehabilitation: a scoping review of the state of the Field. J Occup Rehabil. 2019;29(2):241-73.

23. Word Health Organization. How to use the ICF: a practical manual for using the international classification of functioning and health (ICF). Geneva: WHO; 2013.

24. Statistics Netherlands: Definitions. Available from: https://www.cbs.nl/en-gb/ our-services/methods/definitions?tab=p\#id=person-with-a-migrationbackground. Accessed 24 January 2020 (2020).

25. Felder-Puig R, Griebler R, Samdal O, King MA, Freeman J, Duer W. Does the school performance variable used in the international health behavior in school-aged children (HBSC) study reflect Students' School grades? J School Health. 2012;82(9):404-9.

26. Miller JW, Naimi TS, Brewer RD, Jones SE. Binge drinking and associated health risk behaviors among high school students. Pediatrics. 2007;119(1): 76-85.

27. RIVM, GGD GHOR Nederland: Gezondheidsmonitor Jeugd [Health monitor youth]. Available from: https://www.volksgezondheidenzorg.info/ onderwerp/gezondheidsmonitor-jeugd/inleiding\#node-wijze-van-deelnameggd-regio-aan-gezondheidsmonitor-jeugd-2015. Accessed 08 April 2019 (2019).
28. Carleton RN, Thibodeau MA, Teale MJ, Welch PG, Abrams MP, Robinson T, Asmundson GJ. The center for epidemiologic studies depression scale: a review with a theoretical and empirical examination of item content and factor structure. PLoS One. 2013:8(3):e58067.

29. Radloff LS. The use of the Center for Epidemiologic Studies Depression Scale in adolescents and young adults. J Youth Adolesc. 1991;20(2):149-66.

30. Field A. Discovering statistics using SPSS. London: SAGE Publications Ltd; 2009.

31. Bonnewyn A, Bruffaerts R, Van Oyen H, Demarest S, Demyttenaere K. [the impact of mental disorders on daily functioning in the Belgian community. Results of the study "European study on epidemiology of mental disorders" (ESemeD)]. Impact des troubles mentaux Sur le fonctionnement quotidien de la population belge. Resultats de l'etude "European study on epidemiology of mental disorders" (ESemeD). Rev Med Liege. 2005;60(11): 849-54.

32. Tak YR, Brunwasser SM, Lichtwarck-Aschoff A, Engels RCME. The prospective associations between self-efficacy and depressive symptoms from early to middle adolescence: a cross-lagged model. J Youth Adolescence. 2017;46(4): 744-56.

33. Moksnes UK, Lohre A, Lillefjell M, Byrne DG, Haugan G. The association between school stress, life satisfaction and depressive symptoms in adolescents: life satisfaction as a potential mediator. Soc Indic Res. 2016; 125(1):339-57.

34. Gubbels J, van der Put CE, Assink M. Risk factors for school absenteeism and dropout: a meta-analytic review. J Youth Adolesc. 2019:48(9):1637-67.

35. Aucejo EM, Romano TF. Assessing the effect of school days and absences on test score performance. Econ Educ Rev. 2016:55:70-87.

36. Lee JC, Mortimer JT. Family socialization, economic self-efficacy, and the attainment of financial Independence in early adulthood. Longit Life Course Stud. 2009;1(1):45-62.

37. Bucciol A, Veronesi M. Teaching children to save: what is the best strategy for lifetime savings? J Econ Psychol. 2014;45:1-17.

38. Greenberg MT, Domitrovich CE, Weissberg RP, Durlak JA. Social and emotional learning as a public health approach to education. Futur Child. 2017;27(1):13-32.

39. Dray J, Bowman J, Campbell E, Freund M, Wolfenden L, Hodder RK, McElwaine K, Tremain D, Bartlem K, Bailey J, et al. Systematic review of universal resilience-focused interventions targeting child and adolescent mental health in the school setting. J Am Acad Child Adolesc Psychiatry. 2017:56(10):813-24.

40. Hoare E, Milton K, Foster C, Allender S. The associations between sedentary behaviour and mental health among adolescents: a systematic review. Int J Behav Nutr Phy. 2016:13.

41. Xiao JJ, Chatterjee S, Kim J. Factors associated with financial independence of young adults. Int J Consum Stud. 2014;38(4):394-403.

42. O'Neil A, Quirk SE, Housden S, Brennan SL, Williams LJ, Pasco JA, Berk M, Jacka FN. Relationship between diet and mental health in children and adolescents: a systematic review. Am J Public Health. 2014;104(10):E31-42.

\section{Publisher's Note}

Springer Nature remains neutral with regard to jurisdictional claims in published maps and institutional affiliations.

Ready to submit your research? Choose BMC and benefit from:

- fast, convenient online submission

- thorough peer review by experienced researchers in your field

- rapid publication on acceptance

- support for research data, including large and complex data types

- gold Open Access which fosters wider collaboration and increased citations

- maximum visibility for your research: over $100 \mathrm{M}$ website views per year

At $\mathrm{BMC}$, research is always in progress.

Learn more biomedcentral.com/submission 